\title{
STRENGTH AND DURABILITY PERFORMANCE OF FLY ASH BASED GEOPOLYMER CONCRETE USING NANO SILICA
}

\author{
Sameer Vyas *1, Mohammad Sameer ${ }^{2}$, Shilpa Pal ${ }^{3}$, Neetu Singh 4 \\ ${ }^{* 1,4}$ Central Soil and Materials Research Station, New Delhi, India \\ ${ }^{2}$ Department of Civil Engineering Gautam Buddha University, Greater Noida, U.P., India \\ ${ }^{3}$ Department of Civil Engineering Delhi Technological University, Delhi, India
}

DOI: https://doi.org/10.29121/IJOEST.v4.i2.2020.73

\begin{abstract}
With the increasing infrastructure development across the globe, the demand of cement production increases day by day. However, the production of cement is associated with the emission of large amount of $\mathrm{CO} 2$ causing global warming. Scientist and engineers are in search of a green ecofriendly alternative for concrete production. Geopolymers are rapidly emerging as an alternative to Portland cement as the binder of structural concrete. In this respect, the fly ash based geopolymers shows considerable prospect for application in concrete industry as an alternative binder to the Portland cement. Development of geopolymer concrete using class F fly ash brings many advantages like; enhancing workability, durability, better strength as well as lowering the price. There is not only a reduction in the greenhouse footprint but, also considerable increase in strength and resistivity to adverse conditions.

In order to enhance the performance of Geopolymer concrete, the use of Nano-silica is found to be suitable and practiced by researchers.

Use of Nano materials as fillers in the concrete matrix has proven effective in increasing mechanical and durability properties. This research is based on performance evaluation of geopolymer concrete using different percentage of Nano-silica. It was observed that Geopolymer concrete with Nano-silica (GPC-N) shows good compressive strength as well as durability under aggressive conditions.

The materials performance was also investigated using X-Ray Diffraction technique. (XRD). Results show that the presence of nanosilica enhanced the performance of Geopolymer concrete with respect to strength and durability purposes.
\end{abstract}

Keywords: Geopolymer; Fly Ash; Nano-Silica; Durability; Compressive Strength; Aggressive Conditions.

\section{INTRODUCTION}

Concrete made with Portland cement is the most widely used material on earth. The concrete industry is the largest user of natural resources in the world [1]. Significant increases in cement production have been observed and are anticipated to increase due to the massive increase in infrastructure and industrialization in India, China and South America. It is generally agreed that the production of Portland cement clinker is expensive and ecologically harmful. As one ton of OPC manufactured, nearly one ton of $\mathrm{CO} 2$ is produced depending on the production process adopted [2]. The emissions generated by Portland cement productions are principal contributors 
to the greenhouse gas (GHG) effect. For instance, the production of Portland cement for concrete accounts for an estimated 5 percent of global anthropogenic carbon dioxide [3].

In view of the serious impact of carbon dioxide on the environment and the continued anticipated growth of industrialization and urbanization, there is a need to redirect the building industry away from its overwhelming reliance on Portland cement by developing alternative binder systems.

The two options which have attracted attention as alternative binders are (i) the partial replacement of cement by industrial byproducts like fly ash and slag and (ii) the use of geopolymer binders. The first alternative has been widely researched and abundant information on the fresh and hardened properties of concrete with partial replacement of cement has led to the use of such blended cements $[4,5,6,7,8]$.

The second alternative, geopolymer binders, is an emerging area of technology. Davidovits [9] first proposed that an alkaline liquid could be used to react with the silicon ( $\mathrm{Si}$ ) and aluminum (Al) in a source material of geological origin or in by-product materials such as fly ash and rice husk ash to produce cementitious binders. Because the chemical reactions that takes place in this case is a polymerization process and the source materials are of geological origin, he coined the term, geopolymer ${ }^{\text {ee }}$ to represent these binders. Geopolymers are members of the family of inorganic polymers. The polymerization process involves a substantially fast chemical reaction under alkaline condition on $\mathrm{Si}-\mathrm{Al}$ minerals, that results in a three-dimensional polymeric chain and ring structure consisting of Si-O-Al linkage.[10]. Davidovits showed that higher amount of reactive silica resulted in the formation of higher amount of geo polymeric gel and consequently developed higher mechanical strength. He also reported that the low calcium fly ash based geopolymer concrete was emerging as an alternative low emission binding material compared to OPC concrete.

It has been found that geopolymer concrete has good engineering properties including compressive strength, enhanced tensile strength, bond strength, sulphate and acid resistance and the potential for enhanced durability $[11,12,13]$.

Research based on geopolymer concrete has mostly been restricted to defining the strength and mix proportion variations [14-20]. Nano technology is having an important role in construction field. Supplementary cementitious materials have been a good choice for replacing cement and adding nanoparticles improves the performance of concrete. [21,22, 23]

Integration of nano silica with fly ash based geopolymer concrete has shown better results than the former. Nanotechnology being one of the most promising research fields in the growth and development of the modern industry has also been used to harness optimum results in the concrete industry by providing opportunities to improve the working of the concrete on molecular level and to enhance the properties of the materials. A dense formation of concrete could be achieved by stacking calcium silicate hydrate ( 5 nanometer diameter) molecules in pyramid to reach the highest density of spherical packing i.e. 74\%. The density and hence the strength of the concrete can be substantially increased by imparting nano materials in the interstitial sites of the calcium silicate hydrate structure. 
This paper is based on the research conducted for understanding the behavior and performance of geopolymer concrete using nano silica in different percentages. The mechanical strength analysis was done by compressive strength test using Compression Testing Machines (CTM). The durability properties based on chloride resistance test, sulphate resistance test, acid resistance test, residual alkalinity, fire resistance tests were also integrated. The mineralogical and micro structural assessment of nano silica modified geopolymer concrete properties was evaluated further by the use of X-RAY diffractometer (XDR).

\section{MATERIALS AND METHODS}

The materials used to determine the effect of Nano-silica on strength and durability of fly ash based Geo-polymer concrete specimens are low-calcium dry fly ash as the source material, aggregates, alkaline liquids, water, and nano-silica.

\section{A. Fly Ash}

Low calcium (Class F) dry fly ash obtained from N.T.P.C thermal power plant has been used as the base material. The chemical composition is presented in Table1.

\section{B. Alkaline liquid}

The alkaline liquid was prepared by mixing sodium silicate solution and sodium hydroxide solution $(12 \mathrm{M})$. The sodium silicate solution contained $30 \%$ of solids and $70 \%$ of water.

\section{Nano Silica}

Nano silica of particle size $10 \mathrm{~nm}$ was obtained from Bee-chem Chemicals Ltd., Kanpur.

\section{Aggregates}

Locally available aggregates, comprising $10 \mathrm{~mm}$ size were used and fine aggregate was standard sand which was well within the limit confirming zone--II as per IS Code 383.1970.

Table 1: Chemical composition of fly ash.

\begin{tabular}{|l|c|c|}
\hline Oxides & Test method & Test result \% by weight \\
\hline Silica & IS:1727 & 60.22 \\
\hline Iron oxide & IS:1727 & 4.81 \\
\hline Alumina & IS:1727 & 26.26 \\
\hline $\mathrm{SiO}_{2}+\mathrm{Al}_{2} \mathrm{O}_{3}+\mathrm{Fe}_{2} \mathrm{O}_{3}$ & IS:3812(pt.1) & 91.29 \\
\hline $\mathrm{Clacium}_{\text {oxide }}$ & IS:1727 & 1.84 \\
\hline Magnesium oxide & IS:1727 & 1.71 \\
\hline Total sulphur & IS:1727 & 0.02 \\
\hline Available alkalies & IS:3812(pt1) & 0.26 \\
\hline Loss on ignition & IS:1727 & 0.95 \\
\hline
\end{tabular}

\section{EXPERIMENTAL WORK}

\section{A. Mix Proportions}

The mix proportions for this study was prepared as per standard procedures using nano silica in different proportions. 
Density of concrete $=2400 \mathrm{~kg} / \mathrm{m}^{3}$

- (Flyash + Fine aggregates + Coarse aggregates + Alkaline solution + Nano silica).

- Ratio of Flyash : fine : coarse

- $1: 1.13: 2.25$

- Taken, Alkaline to fly ash ratio $=0.45$.

- Ratio of $\mathrm{NaOH}$ to $\mathrm{Na}_{2} \mathrm{SiO}_{3}=2.5 /$

- $\mathrm{NaOH}: 12 \mathrm{M}$.

- Nano silica added in different percentages. $(0 \%, 2 \%, 4 \%, 6 \%, 8 \%$ by weight of flyash).

The final mix design for making Geopolymer concrete with nano silica (GPC-N) for $1 \mathrm{~m}^{3}$ is given in Table 2.

Table 2: Final Mix Design

\begin{tabular}{|l|l|}
\hline Materials & Quantity $\left(\mathbf{k g} / \mathbf{m}^{3}\right)$ \\
\hline Fly ash & $496.55 \mathrm{~kg}$ \\
\hline Fine Aggregate & $560 \mathrm{~kg}$ \\
\hline Coarse Aggregate & $1120 \mathrm{~kg}$ \\
\hline $\mathrm{NaOH}(12 \mathrm{M})$ & $51.71 \mathrm{Kg}$. solid \\
& $108 \mathrm{lit}$ of water \\
\hline Sodium silicate Gel, containing $70 \%$ of & $63.84 \mathrm{Kg}$. \\
water and 30\% of solids. & (70\% of water) \\
\hline Nano silica & Nano silica added in different percentages i.e. 2\%, \\
& $4 \%, 6 \%, 8 \%$ by weight of fly ash. \\
\hline
\end{tabular}

\section{B. Final Mix Design Proportions for 1 cube}

For the final mix design of GPC-N, the nano silica was added in predefined percentages $(0 \%, 2 \%$, $4 \%, 6 \%, 8 \%$ ) by weight of fly ash. Total 6 Nos. of trial mix designs were casted for this research. 5 trial mix designs were rejected for dearth in strength and durability properties.

\section{Casting of Test Specimens}

\section{Preparation of alkaline liquids}

The alkaline liquid was prepared one day advance of the casting by mixing sodium hydroxide $(\mathrm{NaOH})$ solution of $12 \mathrm{M}$ with sodium silicate solution.

\section{Casting of Fresh geo-polymer Concrete with nano-silica}

The casting of cubes were done as per mix design approach by suitably mixing all ingredients in exact proportions using standard procedures.

The concrete slump before putting it into moulds was measured to be $92 \mathrm{~mm}$ which is medium. The fresh concrete after being put into moulds was compacted properly. 
The process of casting is presented in fig. $1-2$

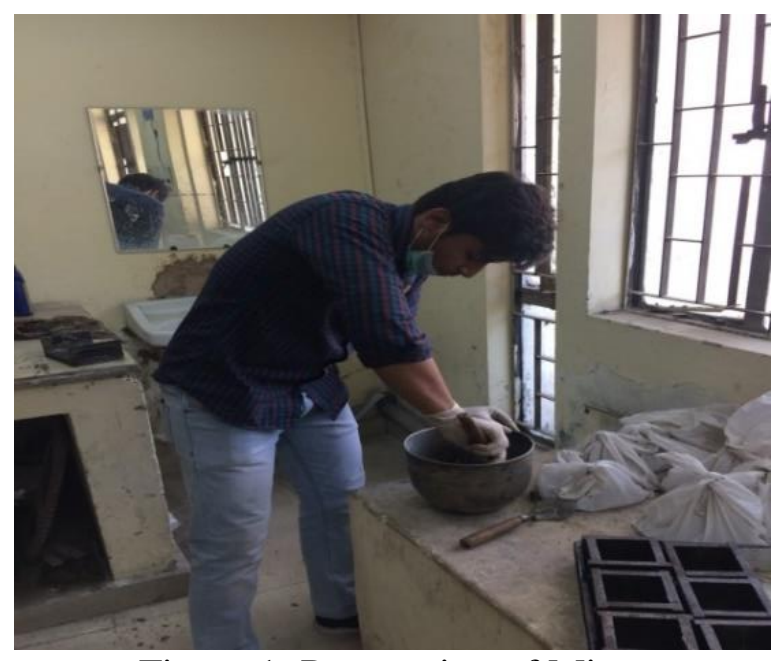

Figure 1: Preparation of Mix.

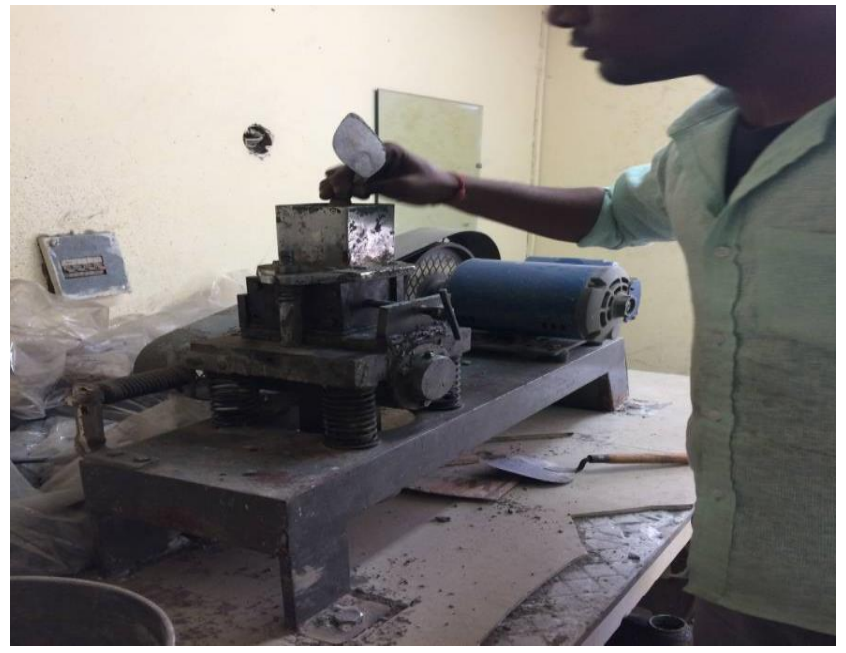

Figure 2: Casting of Concrete cube.

\section{Curing of Test Specimens}

The test specimens were cured in the oven. The specimen were heated at $60^{\circ} \mathrm{C}$ for 72 hours to gain strength. The process of curing is presented in fig.3-4.
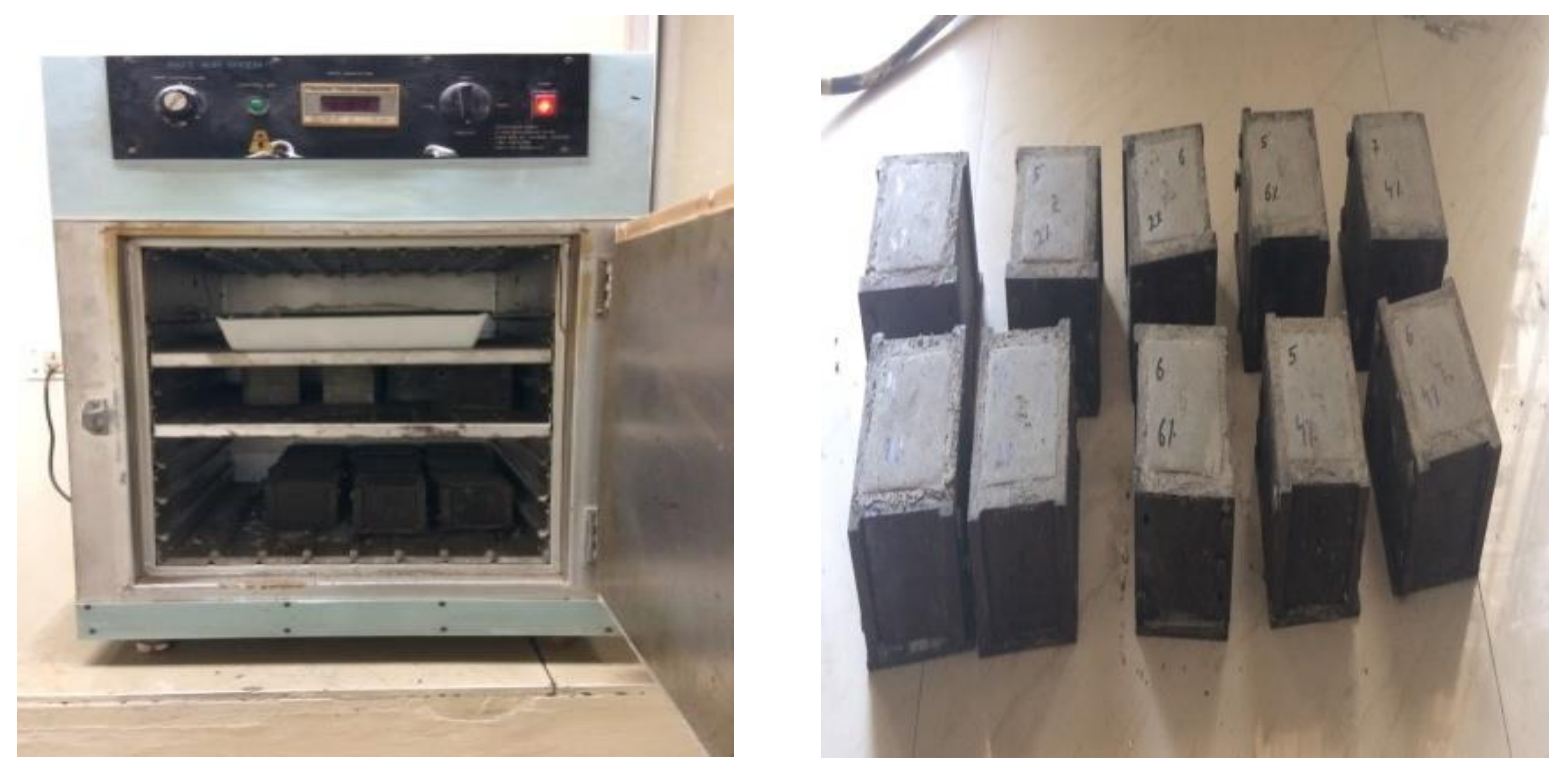

Figure 3, 4: Curing of Concrete Cubes.

After required curing the samples were left to air dry in the laboratory until the day of testing.

\section{E. Strength Property}

\section{Compressive strength}

The 70.6 x $70.6 \mathrm{~mm}$ geopolymer concrete $(\mathrm{GPC}-\mathrm{N})$ ) cube specimens were prepared for each mix proportions of geo-polymer concrete with nano-silica. The specimens were tested for compressive 
strength after 72 hours of casting.. The specimens made from final mix design were cured at $60^{\circ} \mathrm{C}$ for 72 hours, The compressive strength was measured on Compression Testing Machine (CTM).

The GPC-N Cubes are presented in fig.5 and Compression testing machine is presented in Fig. 6.

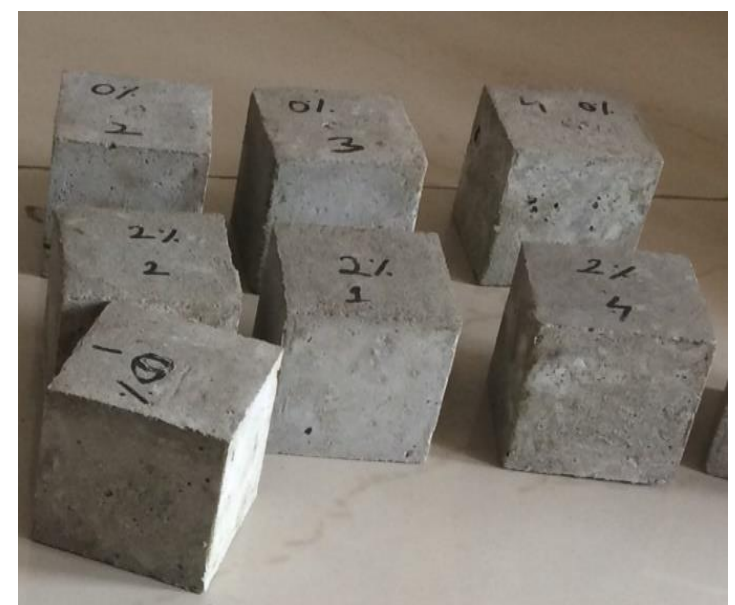

Figure 5: Cured GPC-N Cubes.

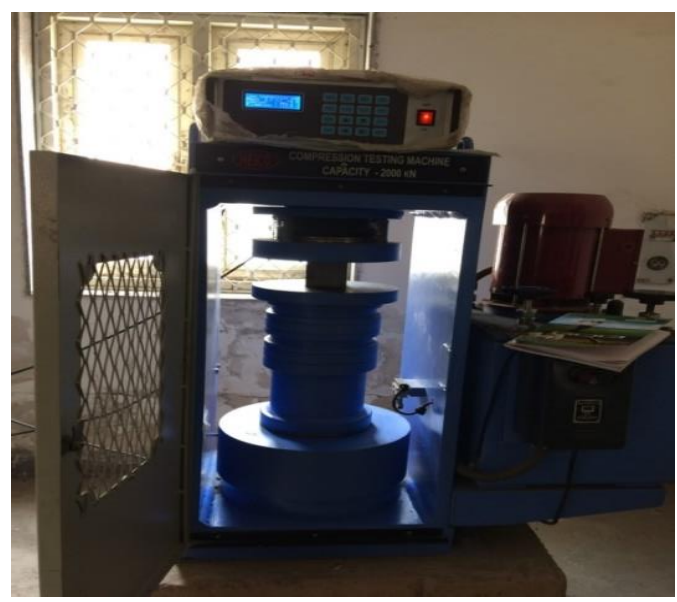

Figure 6: Compression testing machine.

\section{F. Durability Test}

\section{Chloride Resistance}

Marine structures are highly subjected to chloride attack and due to the chloride penetration, the reinforcement is subjected to corrosion. The test specimens of GPC-N were immersed in $10 \%$ sodium chloride solution for the period of 4-8 week exposure. The performance of GPC-N cubes were evaluate on the basis of Change in Compressive strength.

\section{Sulphate Resistance}

Sulphate usually present in ground water or soil which comes into the contact of concrete and affects it. The test specimens were immersed in $10 \%$ Sodium sulphate $\left(\mathrm{Na}_{2} \mathrm{SO}_{4}\right)$ solution. The performance of GPC-N cubes after exposures of 4-8 weeks were evaluate on the basis of Change in Compressive strength.

The exposure of GPC-N cubes in Chloride \& Sulphate ion solution is presented in fig. 7.

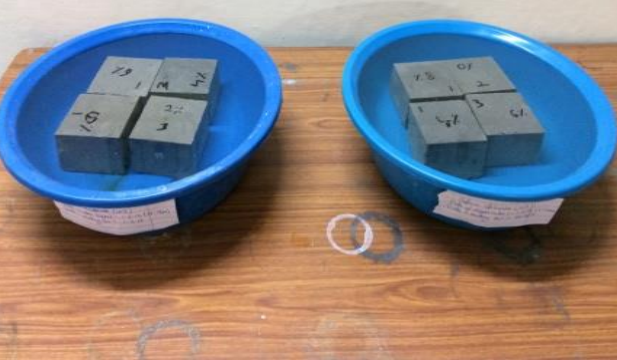

Figure 7: Exposure of GPC-N cubes in Chloride \& Sulphate ion solution. 


\section{Acid Resistance}

The acid resistance test was performed to study the effect of Sulphuric acid $\left(\mathrm{H}_{2} \mathrm{SO}_{4}\right)$ and Hydrochloric acid $(\mathrm{HCl})$ on GPC-N specimens. The test specimens of GPC-N were immersed in $3 \% \& 5 \%$ solutions of concentrations of sulfuric and hydrochloric acid for 4-8 weeks exposure. The performance of GPC-N specimens were than evaluate on the basis of Change in compressive strength.

\section{G. X-Ray Diffraction Test}

$\mathrm{X}$-ray diffractometer test is a non-destructive testing used for the characterization and identification of crystalline materials.

The samples for XRD test were prepared by crushing the GPC-N concrete cube particles and passed through 100-micron sieve. The samples of flyash, Nano-silica, and crushed cubes samples after test of compressive strength and durability were taken to study XRD pattern.

\section{RESULTS AND DISCUSSIONS}

\subsection{Compressive Strength}

The results for compressive strength for Final mixed design is presented in table 3 and Fig.8. With the increase in the percentage of nano silica there is an appreciative increase in the strength up to $8 \%$. Addition of nano silica beyond $8 \%$ decreases the strength by makes the concrete brittle.

Table 3: Compressive Strength for Final Mix Design with Different Percentage of Nano silica.

\begin{tabular}{|l|c|c|c|c|c|c|}
\hline & \multicolumn{5}{|c|}{ Compressive strength in (MPa) } \\
\hline $\begin{array}{c}\text { Nano silica } \\
\mathbf{0 \%}\end{array}$ & $\begin{array}{c}\text { Nano silica } \\
\mathbf{2 \%}\end{array}$ & $\begin{array}{c}\text { Nano silica } \\
\mathbf{4 \%}\end{array}$ & $\begin{array}{c}\text { Nano silica } \\
\mathbf{6 \%}\end{array}$ & $\begin{array}{c}\text { Nano silica } \\
\mathbf{8 \%}\end{array}$ & $\begin{array}{c}\text { Nano silica } \\
\mathbf{1 0 \%}\end{array}$ \\
\hline $\begin{array}{l}\text { Final } \\
\text { mix } \\
\text { design }\end{array}$ & 24.0 & 26.7 & 29.8 & 32.0 & 35 & 31.7 \\
\hline
\end{tabular}

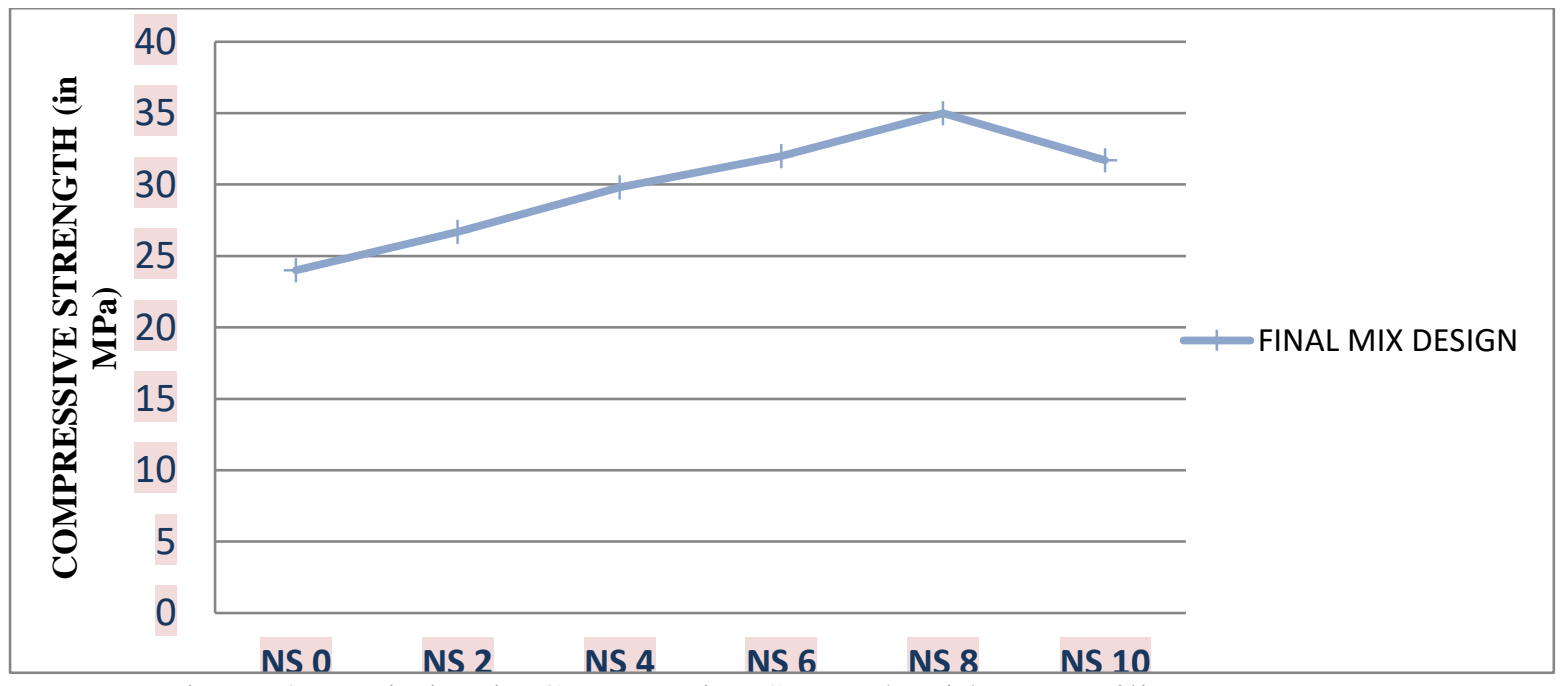

Figure 8: Variation in Compressive Strength with Nano silica percentages. 


\subsection{Durability Tests}

\section{Effect of Chloride Ion Exposure on Compressive Strength of GPC-N Cubes.}

The compressive strength of these test specimens without any exposure of chloride solution was taken as the initial (reference) compressive strength. The test results for 4-8 weeks exposure periods are presented in Fig.9.

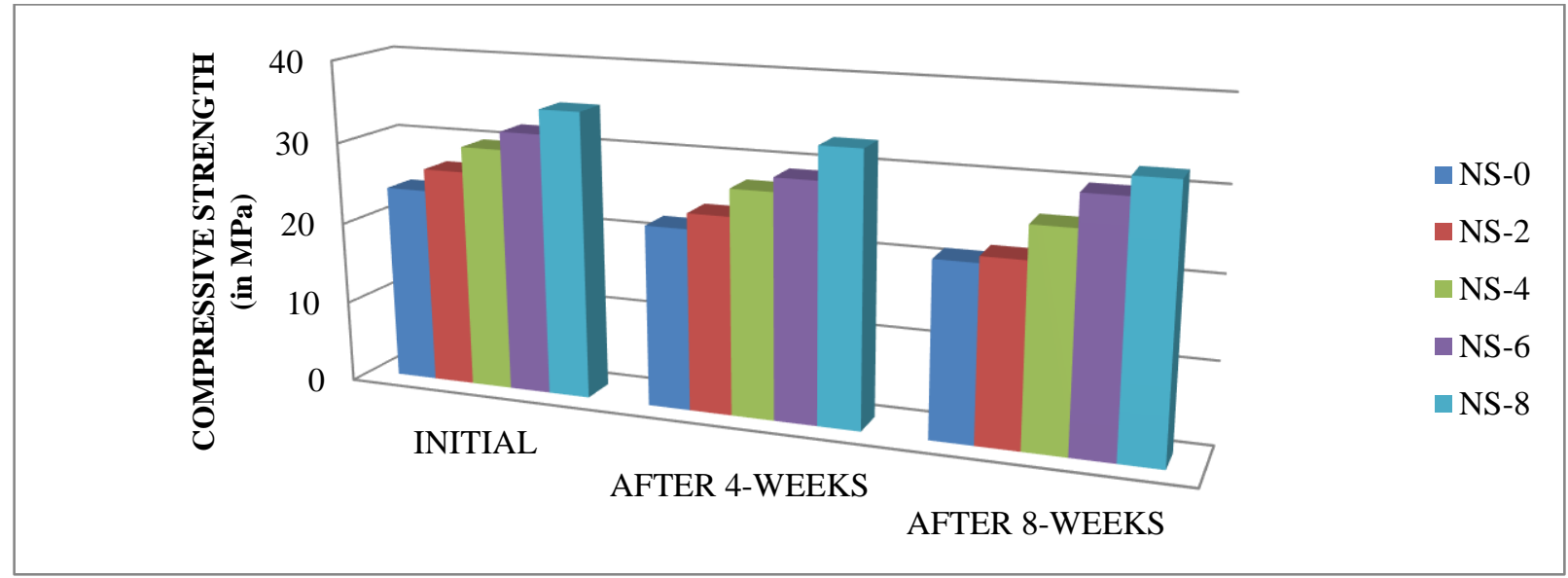

Figure 9: Compressive Strength after Exposure of GPC-N cubes in Chloride Solution.

These test results for chloride resistance depict that the GPC-N cubes exposed to $10 \%$ sodium chloride solution for 4-8 weeks shows very little change in compression strength. Therefore, geopolymer concrete is shows remarkable resistance to chloride exposure.

\section{Effect of Sulphate Ion Exposure on Compressive Strength of GPC-N Cubes.}

The test results for initial reference and 4-8 weeks exposure periods are presented in Fig.10

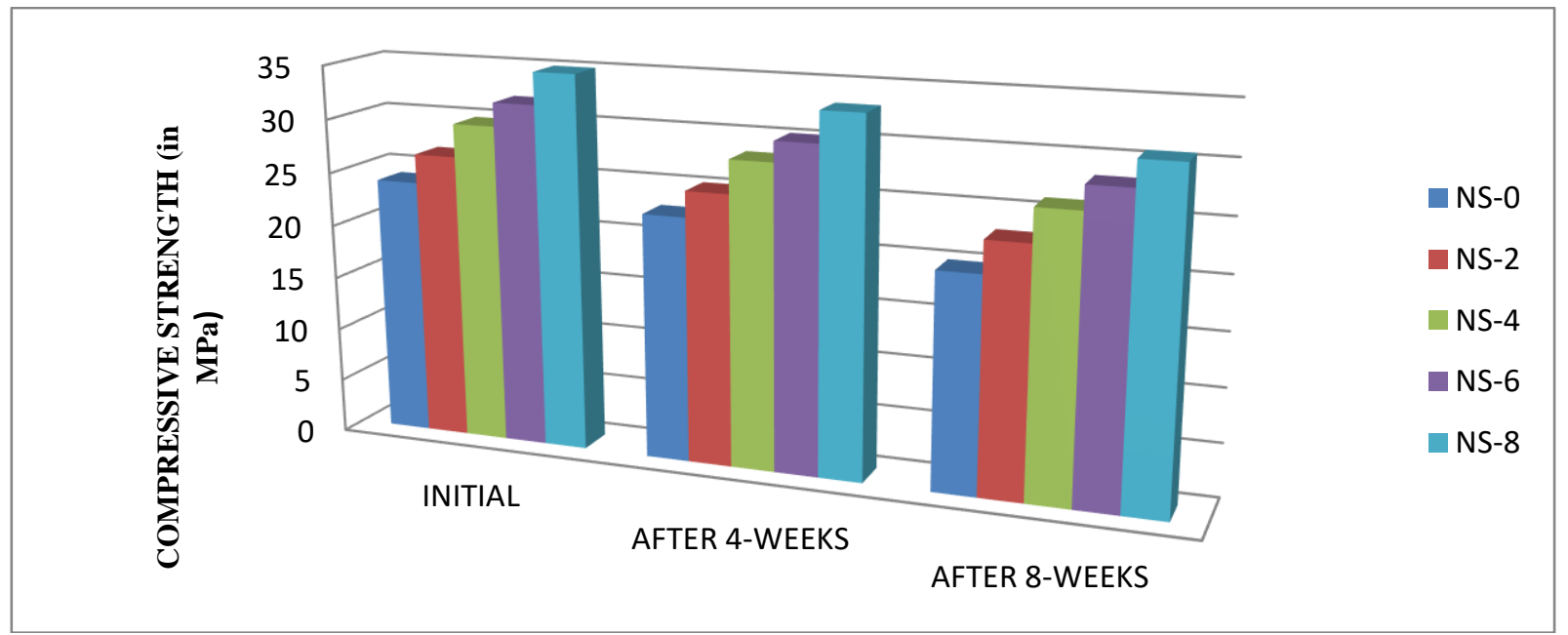

Figure 10: Compressive Strength after Exposure of GPC-N cubes in Sulphate Solution.

Very small change was observed after the exposure of GPC-N cubes in $10 \%$ sodium sulphate solution. However, GPC-N with 8\% Nano silica shows good resistance to Sulphate exposure. 


\section{Change in Compressive Strength After Exposure in Acid Solutions}

The change in compressive strength of GPC-N test specimens exposed to 5\% solution of sulphuric and hydrochloric acid solution are presented in fig. $11 \& 12$.

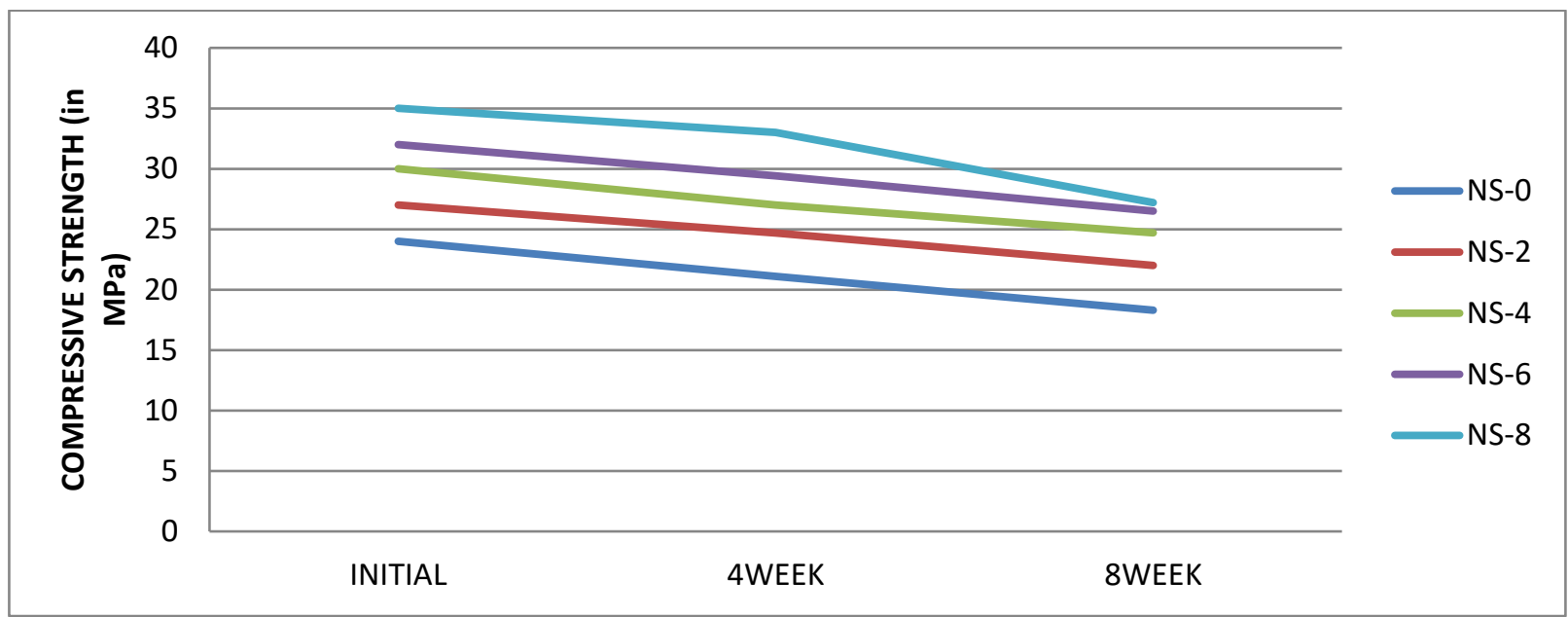

Figure 11: Change in Compressive Strength of GPC-N

Specimens Exposed to 5\% Sulfuric Acid Solution.

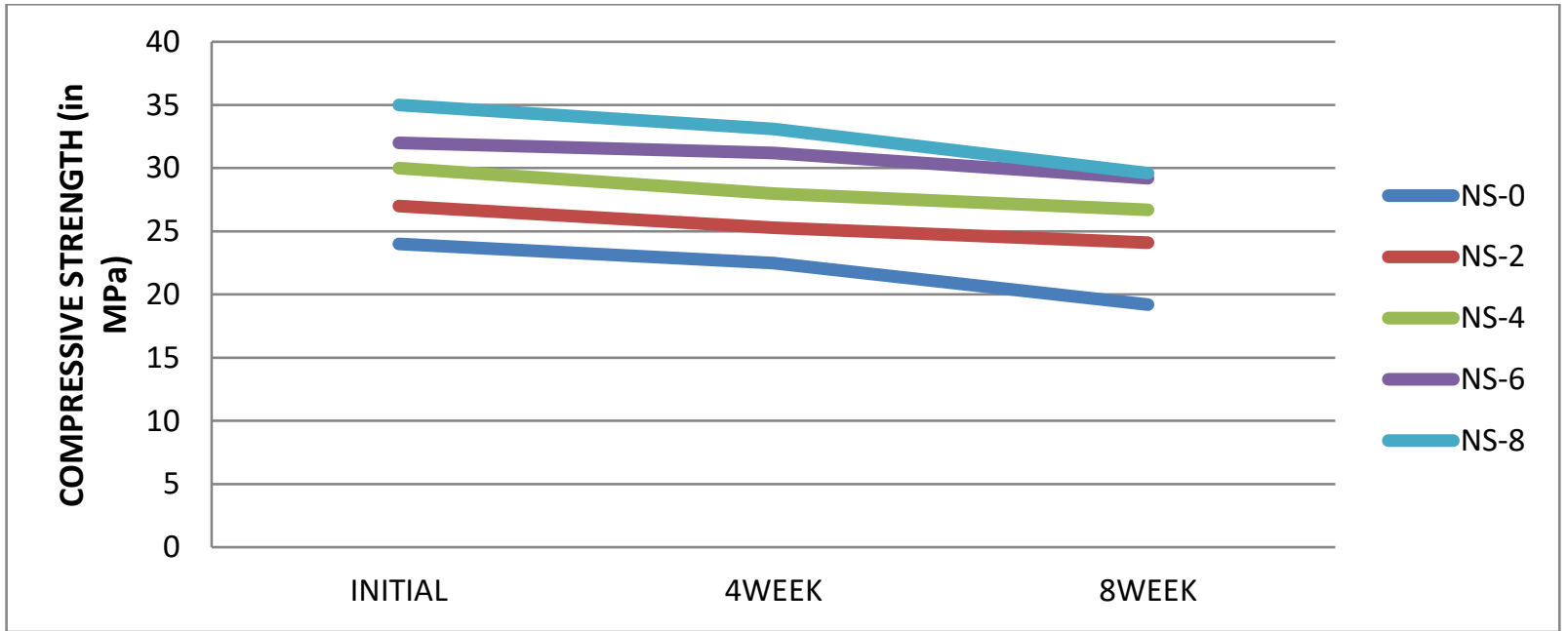

Figure 12: Change in Compressive Strength of GPC-N Specimens Exposed to 5\% Hhydrochloric Acid Solution.

The plain geo-polymer concrete specimen shows $20 \%$ reduction in strength whereas in GPC-N, $16 \%$ reduction in compressive strength was observed which suggested that the GPC-N specimen having good acid resistance. The concentration of acid and period of exposure are the key parameters which are responsible for degradation in strength property.

\subsection{Mineralogical Characteristics}

The Fig:13 represents XRD spectra obtained for Fly ash and Plain GPC. 


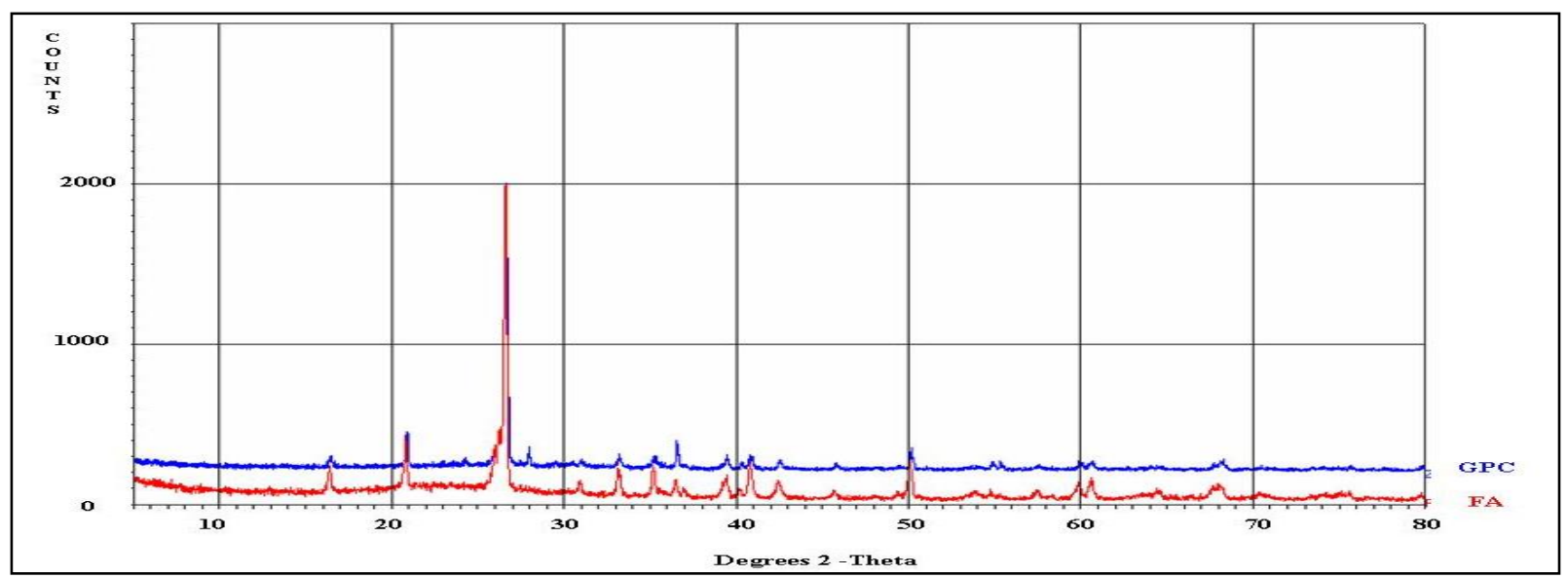

Figure 13: XRD pattern of fly ash and GPC

The pattern of XRD analysis shows that besides crystalline phase composed of quartz and mullite, Flyash is primarily composed of amorphous material. On geo-polymerization process the peaks represents the amorphous phase of fly ash appears slightly shifted towards higher theta values which shows the transformation of fly ash amorphous phase into new geo-polymer concrete amorphous phase. These new diffraction peaks are mainly due to the formation of new crystalline zeolitic phases such as hydroxysodalite, analchime and herschelite. Fig 14 represents the XRD pattern of GPC-N specimens.

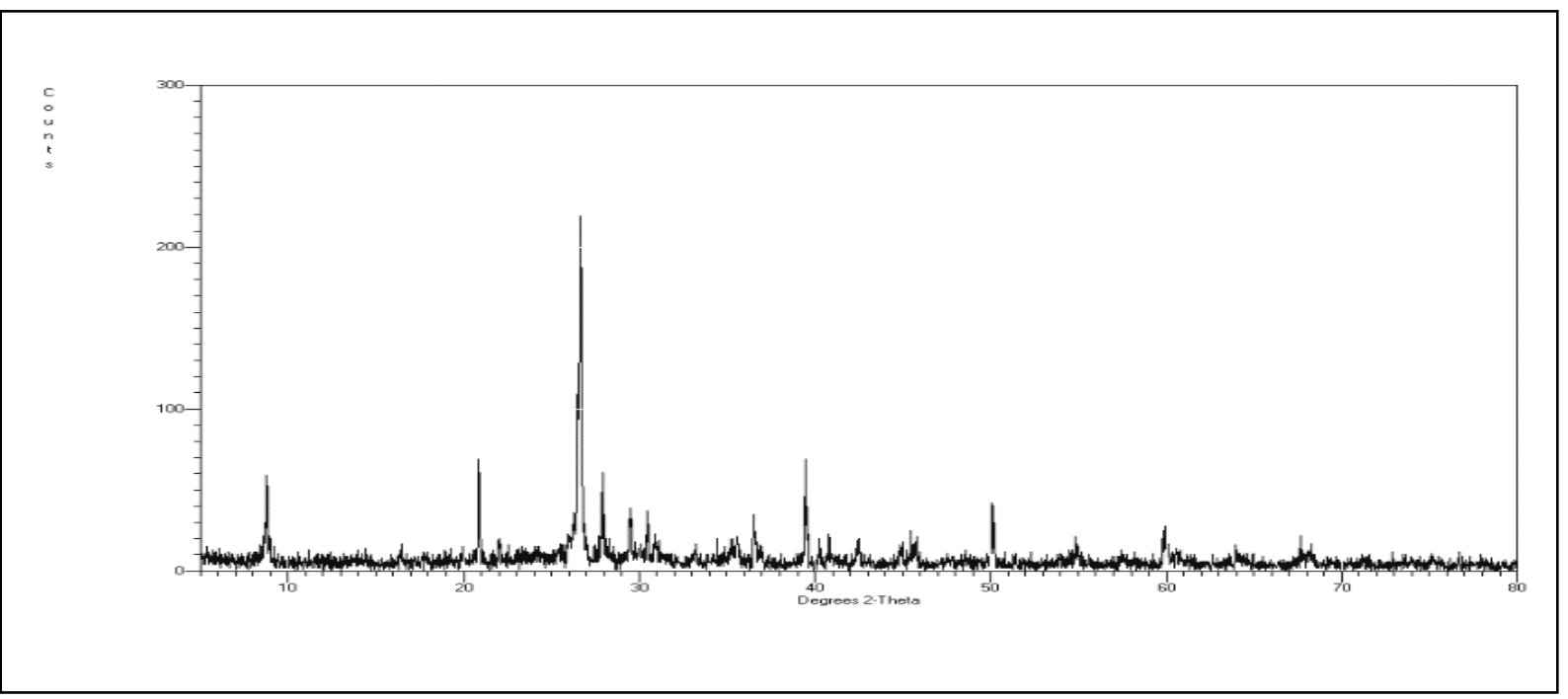

Figure 14: XRD pattern of GPC-N

The XRD analysis pattern shows that the geopolymer concrete with $8 \%$ nano silica addition, some specific extra peak positions are observed. It indicates the formation of new crystalline phase as compared to the geo-polymer concrete without nano-silica samples.

\section{Conclusions and Recommendations}

The following conclusions have been drawn from the study of effect of Nano-silica on the strength and durability of fly ash-based geopolymer concrete. The GPC-N cubes were casted with five 
different percentages of nano silica i.e. $0 \%, 2 \%, 4 \%, 6 \%$, and $8 \%$ by weight of fly ash respectively. The outcome of the different tests conducted on these GPC-N concrete cubes are summarized as follows: -

1) The compressive strength of GPC-N increased with increase in the nano silica percentage up to $8 \%$ due to low permeability and dense geopolymer concrete matrix, as compared to geopolymer concrete without nano silica, at controlled curing temperature and curing period.

2) The chloride and sulphate intrusions were minimum in GPC-N cubes with $8 \%$ nano silica. The rate of decrease of compressive strength in GPC-N decreased with the addition of nano silica. Tests also indicated that there was no formation of ettringite or gypsum from the main products of polymerization in GPC-N.

3) The GPC-N cubes with $8 \%$ nano silica showed fair resistance to acid environment as the decrease in compressive strength was marginal. With the increase in $\mathrm{HCl}$ and $\mathrm{H}_{2} \mathrm{SO}_{4}$ concentration there was a decrease in the compressive strength and rate of surface erosion, however the acid resistance was better than that of geopolymer concrete without nano silica.

4) The investigations so far have indicated that geopolymer concrete with nano silica addition have found potential replacement for the OPC in concrete. The GPC-N also performed well in different environments.

\section{Acknowledgements}

The authors are extremely thankful to all the officers and staff of concrete technology division for extending laboratory facility and arrangement of materials required for testing work.

\section{References}

[1] Mehta, P. K. "Greening of the Concrete Industry for Sustainable Development", ACI Concrete International, 24(7), 2002, pp.23-28.

[2] McLellan BC, Williams RP, Lay J, et al. Costs and carbon emissions for geopolymer pastes in comparison to ordinary Portland cement. J Clean Prod 2011, 19: 1080-1090.

[3] Karstensen, K.H., "Cement Production in Vertical Shaft Kilns in China -Status and Opportunities for Investment," UNIDO Contract RB-308-D40-8213110-2005, 2006.

[4] Mehta, P. K. "High Performance, High Volume Fly Ash Concrete for Sustainable Development" in Proceedings of International Workshop on Sustainable Development and Concrete Technology, Beijing, China, 2004, pp. 3-14.

[5] Stevenson, M. and Panian, L. "Sustainability through Strength" Concrete International, 31(3), 2009, pp. 34:39.

[6] Poon, C. S., Lam, L. and Wong, Y. L. "A Study on High Strength Concrete Prepared with Large Volumes of Low-Calcium Fly Ash", Cement and Concrete Research, 30(3), 2000, pp.447-455.

[7] Papadikis, V. G. "Effect of Fly Ash on Portland Cement Systems, Part I: Low-Calcium Fly Ash" Cement and Concrete Research, 29(11), 1999, pp. 1727-1736.

[8] Malhotra, V. M. "High-Performance High-Volume Fly Concrete", Concrete International 24(7): 2002, pp. 30-34.

[9] Davidovits, J. "Geopolymers: inorganic geopolymeric new materials" Journal of Thermal Analysis, 37, 1991, pp. 1633-1656.

[10] Davidovits J. Chemistry of geopolymeric systems, terminology. In Proceedings of the 2nd International Conference on Geopolymer, Saint-Quentin, France, 1999: 9-39. 
[11] Sofi, M., van Deventer, J. S. J., Mendis, P. A. and Lukey, G. C. "Bond performance of Reinforcing Bars in Inorganic Polymer Concrete (IPC)", Journal of Materials Science, 42(9), 2007, pp. 31073116. 65.

[12] Sofi, M, van Deventer J, S. J., Mendis, P, A, and Lukey G. C. "Engineering Properties of Inorganic Polymer Concretes (IPCs)" Cement and Concrete Research, 37(2), 2007, 251-257.

[13] Provis, J. L., Muntingh, Y., Lloyd, R. R., Xu, H., Keyte, L. M., Krivenko, P. V. and van Deventer, J. S. J "Will Geopolymers Stand the Test of Time?" Ceramic Engineering and Science Proceedings, 28(9), 2007, 235-248.

[14] Pal S, Mandal S. Different thermal activation effect on fly ash based geopolymer concrete. Indian ConcrInst J 2011; 12:23-5.

[15] Daniel LYK, Jay GS. Effect of elevated temperatures on geopolymer paste, mortar and concrete. CemConcr Res 2010; 40:02.

[16] Chindaprasirta P, Rattanasakb U, Taebuanhuadb S. Role of microwave radiation in curing the fly ash geopolymer. Adv Powder Technol 2013; 24:03.

[17] Peigang H, Dechang J, Meirong W, et al. Thermal evolution and crystallization kinetics of potassium-based geopolymer. Ceram Int 2011; 37:01.

[18] Hussin MW, Bhutta MAR, Azreen M, et al. Performance of blended ash geopolymer concrete at elevated temperatures. Mater Struct 2014.http://dx.doi.org/10.1617/s11527- 014-0251-5.

[19] Vijai K, Kumutha R, Vishnuram BG. Effect of types of curing on strength of geopolymer concrete. Int J PhysSci 2010;5(9).

[20] Guo X, Shi H, Dick WA. Compressive strength and microstructural characteristics of class C fly ash geopolymer. Cement Concr Compos 2010; 32:2.

[21] T.R.P raveenkumar, M.M. Vijayalakshmi, Effect of Nano particles on the properties of concrete, International journal of chemtech, Vol.8, No.7, 2015, pp 50-55.

[22] T.R. Praveenkumar, M.M. Vijayalakshmi , M.S. Meddah, Strengths and durability performances of blended cement concrete with $\mathrm{TiO}_{2}$ nanoparticles and rice husk ash, Construction and Building Materials 217 (2019) 343-351.

[23] KotiChiranjeevi, M.M. Vijayalakshmi, Praveenkumar T R Behaviour of Fly Ash based Geopolymer Concrete using Nano-Material International Journal of Innovative Technology and Exploring Engineering (IJITEE) ISSN: 2278-3075, Volume-8 Issue-12, October 2019,4436-4439.

*Corresponding author.

E-mail address: samyog78@ yahoo.com 